\title{
Whither the Community? Lessons Madagascar Can Learn from Israel's Water Policy
}

\author{
Richard R. Marcus \\ California State University, Long Beach, USA \\ Email: richard.marcus@csulb.edu
}

Received March 23, 2012; revised July 7, 2012; accepted August 2, 2012

\begin{abstract}
Madagascar wrote a fundamentally new Water Code in 1998. It focused on maximizing the number of people with access to clean water through a process of decentralized water management and cost recovery. This paper is concerned with the policy problem this presents at the community level—is Malagasy water law the best possible for the country? Combining community-level focus group studies and policy analysis, this study examines Malagasy water policy shifts focusing on localization of water governance to parallel localization efforts in Israel. This study concludes that Madagascar's water policy is flawed. Using a case study from the arid south this study explores the impact of these alternatives to ineffective state-centric policies. Comparing to Israel's policy process this study finds that the Malagasy policy process has not been a process at all, the institutions are not in place, and the requisite levels of investment are not forthcoming. Rather than empowering communities as stewards of their own resources, community level management has been undermining effective governance by allowing the state to recede, and minimizing economic resources, while ignoring local capacity, local will, and increasing local water poverty.
\end{abstract}

Keywords: Madagascar; Israel; Water Policy

\section{Introduction}

One must evoke the more fantastic compositions of GustaveDoré illustrating the stories of sorcerers or of Riou creating imaginary worlds for Jules Verne, if one wants to have an idea of what is here. It is unreal. No plants, not a tree that has a familiar aspect. One walks in a full forest, but a forest of underwater dreams, a forest of trees without leaves, of large euphoribia which are named fanitholosse, made out of large sinister stumps there is no water, it rains almost never.

—Hubert Lyautey [1]

When Lyautey wrote this in a letter to his sister on July 7, 1901 he was describing the Ambovombe region of Madagascar and its unique spiny forest. France had colonized the island five years before and was trying to figure out how to govern it. Lyautey was charged by the then governor, General Joseph Gallieni, with assessing what the great work must be, organizing an administrative budget for the new colony, and installing armaments in Diego-Suarez to protect against looming conflict with Great Britain. Most importantly, he was to assess the potential risks and threats to the stable rule of the island. In considering what this meant for the Ambovombe region he concludes (p.136) that "Here he who controls water, controls the country". His answer was to make significant investments into the growth of cattle herding and to create water infrastructure for control of the resource.

His findings should not have been surprising to either his sister or Gallieni. Two and a half centuries earlier the French East Indian Company had attempted to colonize the island. The company installed Etienne de Flacourt as Governor. He failed and returned to France (ultimately becoming Director General of the Company), but not before surveying large portions of the south. He wrote that "It is a country without rivers and without water until Manambouve, except a few ponds here and there the country is dry and arid for agriculture but good for pasturage" [2].

In such an austere environment one commonly finds indigenous management systems in place to cope with scarcity. Yet, there is archeological evidence that current disregard for water systems in the local Antandroy communities is long-standing. Unlike their Antanosy neighbors, Antandroy developed semi-nomadic coping strategies instead of infrastructure systems [3-5]. Before the $9^{\text {th }}$ century CE people sustained themselves on hunting and gathering. Trade developed over the three decades that followed, a hierarchical social organization development in the $14^{\text {th }}$ and $15^{\text {th }}$ centuries, trade systems were transformed by European contact between the $16^{\text {th }}$ and $18^{\text {th }}$ 
centuries, and a modern economy was implemented by the French thereafter. But, at no point did an indigenous culture of resource protection or management emerge.

One would think that, on observing this, Flacourt would have sought a resource management regime as a means of control. He didn't. Lyautey did not impress upon Gallieni such a call. Why not? After all, there is a long history of using water regimes as a means of control -Egypt, Mesopotamia, India, China and pre-Columbian Mexico and Peru to draw on those famously cited by Karl Wittfogel [6]. If ever there was a place where he who controls water controls the population, this was it.

It didn't happen. While there was a minor canal system established by the French, there was never the creation of a significant water management system. Not for the betterment of local life nor for purposes of controlling local populations. Rather, colonial rule forced the semi-sedentarization of the population without creating a supportive resource infrastructure. Cattle herding was encouraged, but along side it agricultural taxation mandated the growth of riziculture. The result? Regularized famine. It would not be an overstatement to say that the concomitant change of socioeconomic system and markets on the one hand, and the lack of water resource investment on the other, ensured that things would fall apart. It was a transition, not a moment, but it was nonetheless dramatic.

Madagascar won its independence from France in 1960. Certainly once freed of the repressive French economic yoke the new government would better assess and act upon the needs of the people in the regime. It would invest in water resource governance. Indeed not. The most critical water legislation of the period, Ordonnance No. 60-173, starts with an exposition that "Water is an essential element for all human and economic activity and is one of the resources whose exploitation will be developed in an accelerated manner for the future of Madagascar.” It goes on to discuss how in certain regions we must rely on groundwater resources and thus the necessary research must be done to exploit relevant aquifers. Critically, it maintains that all groundwater resources became the property of the state for the collective benefit of the population (this element has remained). But it did not set the stage for infrastructure investment.

The research referred to in the Ordonnance was not conducted for the better part of three decades. As the Antandroy population grew at one of the fastest rates in the country, agriculture was still encouraged by markets and water resources were left without broader governance or significant investments. By the late 1980s the seesaw imbalance between market incentives and wanting water resource infrastructure led to the regularized need of World Food Program (WFP) intervention. The WFP began intervening at an average of almost one crop season per year-a humanitarian mandate but a market catastrophe. In 1996 the Malagasy government began working with the European Union to set up a famine early warning system. Ambovombe is the regional headquarters for the project which regularly assesses the situation, releases an information bulletin of food and water crises by zone, and intervenes with food aid. But, in a continuation of ad hoc policies addressing the symptoms not the cause, it also did not set up a comprehensive water management plan. In a statement reminiscent of Lyautey and Ordonnance No. 60-173, the The Government of Madagascar [7] noted:

It is true that if money strikes the nerve of war, it is also true that water is life. It is in effect more necessary to demonstrate the importance of the role that is played by water in the development and the competitiveness of the economy, than in the amelioration of the conditions of life for the population. This reality put into evidence necessitates the establishment of a rational policy of drinking water supply and sanitation, and to put in place a management policy for the sector.

Unfortunately, these were not indicative of more significant measures to come. As a result of a century of resource imbalance Ambovombe is a region in crisis. Literacy, now 24 percent, is among the lowest in the country. Available income, under 3,000,000 FMG (about $\$ 476)^{1}$ per annum is the lowest of any region in the country. Despite significant cattle herding, about half of the population has no regular opportunity to eat meat (Droy and Dubois 2002). Disease rates have skyrocketed and life expectancy has plummeted. The social impact has been equally devastating with considerable animosity between Antandroy and those of dominant Merina extraction. As describe by a notable Malagasy scholar ${ }^{2}$, the Antandroy of the extreme south are not like other Malagasy They are not able to live as long or think as well. It is not their fault really. They are physiologically incapable of higher thought.

Madagascar wrote its first Water Code in 1998. The Code's primary point is that water should be universal, well-managed, and commodified. Cost recovery was codified as a part of financing existing water services and hoped-for improvements. In urban areas this effectively meant that the national water carrier and electrical company, JIRAMA, would be privatized. This process is nearly complete. Some urban areas are even seeing their water sectors revamped by public-private partnerships. Conflicts over urban water resources, such as that sur-

\footnotetext{
${ }^{1}$ Droy and Dubois mark incomes significantly higher than Marcus in a neighboring Anosy region. This is most likely due to the measurement method. Whereas Droy and Dubois include any salary plus all assets, both fixed and consumable, Marcus includes only consumable [8,9].

${ }^{2}$ Given the content of the statement, I will leave the quote anonymous. It does, nonetheless, represent a view indicative of Merina attitudes towards Antandroy.
} 
rounding Antarambiby, a primary source for the regional city of Fianarantsoa, are being addressed with varying levels of success. What of the other 77 percent of the population that lives in rural areas? This issue is less clear. Policies are limited in scope if they exist at all. Decentralization and privatization, a global water management mantra, is being implemented even as it is unclear if communities are up to the task.

While a roadmap has been drawn, the quality of the road is far from assured. Madagascar's new water policy is flawed. It has political problems and policy problems. The political problemic: does the Malagasy government have both the capacity and will to undertake the sort of changes necessary. Since the Water Code was written in 1998 there have been two significant political events. President Marc Ravalomanana rose through an election followed by a large social movement in 2002. He was ousted by the military in March 2009 and replaced by AndryRajoelina. While a critical topic to Malagasy governance, the water sector policy framework has done little. If anything it has delayed sector development without creating policy resolves. The highly politicized rotating door-and institutional structure - of the Ministry of Water has contributed to this legal-juridical quagmire. It has, however, remained largely an urban issue with rural production water, the focus herein, largely unaffected. The political discussion about sectoral governance is an important separate topic of its own and not addressed herein ${ }^{3}$.

This paper focuses on the policy problem-is new Malagasy water law, so very long in coming, the best possible for the country? I argue that the lack of vision, process, institutional realization, and investment are likely to undermine Malagasy development while ensuring the thirst of the Malagasy people. Moreover, the policy process has undermined the effective building of JIRAMA while driving the state to virtually abandon the water sector.

This paper begins with a brief history of Malagasy water infrastructure. It then goes on to describe what the system looks like today and is intended to look like once complete, before turning to discuss how this is manifest in the Ambovombe region in Madagascar's extreme south. Concluding that Madagascar's new water policy needs reform, I then turn to discuss Israel's water sector policy shifts in an effort to learn lessons about how policies can be written "better". While the comparison

\footnotetext{
${ }^{3}$ For a discussion of the political events of 2002 and their consequences see R. Marcus [9]. For a discussion of the political events of 2009 see S. Randrianja [10]. For a discussion of how the governance of different sectors can be impacted by political change see World Bank 2010 [11]. ${ }^{4}$ Israel's water sector is highly problematic as it is fraught with factionalism. However, this is a political problem. The new policy paradigm, I argue here, makes sense. It is only a matter of whether there is the political will to fully implement it.
}

might seem unusual at face value, it has merit at a policy level. Both countries have relatively mild central regions, high precipitation in the north, and semi-arid to arid conditions in the south. Both Malagasy and Israeli water policy structures are in a period of significant flux, moving them from highly centralized public systems to more decentralized partially privatized systems. In both cases "communities" are expected to take up the slack left from the disengagement of the state. In both cases those in the most arid regions are the poorest in the country, with least access to the state. In both cases a relatively large percent of the population has been sedentarized by the state apparatus and a disjuncture remains from that process. Most importantly, when Israel embarked on the creation of water infrastructure in 1953 it was a developing country itself with an economy in tatters and few economic resources for public investment.

The obvious difference between Madagascar and Israel today is one of economic scale. Israel has per capita incomes 40 times that of Madagascar. Perhaps more importantly, infrastructure investments have been significant over a fifty-year period. I will argue that ultimately this difference of economic scale transcends relative development conceptions linked to artificial, obfuscating distinctions made between "developed" and "underdeveloped" countries. The difference in economic scale differentiates levels of power across scales, but the need for regularized water supply and sound water governance is constant. That was recognized in Israel half a century ago, but not in Madagascar today. Where all stakeholders in Israel, including farmers, engage the process, in Madagascar the process is opaque, created in a vacuum by the external few. As a result, Madagascar has adopted an ad-hoc water management system lacking in vision and put together in haste. Ultimately, this will be its failure.

\section{The Water System: Where It Comes from, What It Is, What It Is Supposed to Be}

At independence in 1960 Malagasy water supply was controlled by the SEEM. In 1974 the SEEM was nationalized and renamed JIRAMA (JirosyRano Malagasy or Malagasy Electricity and Water). Madagascar has six provinces, each with a provincial capital, and JIRAMA infrastructure was limited almost exclusively to those six urban areas. There were state investments in SEEM in the 1960s and JIRAMA in the 1970s, but they were not intended to grow infrastructure beyond the six key cities.

During the colonial era the French had created limited, localized irrigation canals in some areas to promote riziculture and other forms of agriculture. In the central highlands of the country this complimented existing indigenous terracing techniques long in use. These efforts were not connected to one another or to SEEM. Therefore they did not become part of JIRAMA nor part of a 
greater water system.

State-led growth of the late 1970s did invest in some regional canal development in rural areas, but efforts were limited. Then President Didier Ratsiraka was a scientific socialist and was focused on regional industrialization to the expense of agriculture. Water was not a consideration. The first real attempts to address water concerns in rural areas came with (mostly foreign) nongovernment organizations sponsored by international donors in the 1980s. These efforts were, and are, generally grassroots projects building gravity-fed water delivery systems, modest river diversions, or other village-level efforts.

In 1994 Madagascar began a process of decentralizetion (Lois 94-001 à 94-008). Shortly thereafter (Loi 95005) budgets began being allocated to decentralized collectivities, and a constitutional amendment (April 1998) created a "regional unitary" state with "autonomous provinces" governing the decentralized collectivities. A 2004 Executive Order (codified in a 2007 constitutional revision) replaced the autonomous provinces with 22 regions. This was followed in 2010 by a new constitution of the Fourth Republic which blends autonomous provinces with regions. While the political divisions of the country have been fluid, in the water sector Madagascsar has continued to follow a decentralized, cost recovery-oriented path. The problem is that this attempt at multilevel resource governance has not created "complex adaptive systems” [12]. There is a central authority and a majority rather than a minority is left out of the decision-making process. The institutional fit does not appear to reflect the human and environmental resource needs. Less than ten percent of people in rural Madagascar have access to clean water and agriculture remains at the margins of water policy despite the fact that livelihoods of nearly 80 percent of the population depends on it. The reasons for this are based in a flawed interpretation of decentralization in the sector. Instead of creating complex adaptive systems water law has led to a state that abandons the water sector. JIRAMA, a fully government owned corporation, struggled in the mid-2000s and failed at attempts to privatize. It was saved through significant World Bank interventions in 2006 and 2008. Today it stands as a testament to failed utilities. By 2011 total government water and sanitation spending per capita plummeted to \$12.95 per capita (Government of Madagascar Budget Data). Remaining costs are shouldered entirely by end users.

\subsection{Ambovobe}

Ambovombe-Androy is a fivondronana (prefecture) of approximately 184,000 people on the extreme southern tip of Madagascar. The firaisana (sub-prefecture) of Ambovombe is the administrative capital and home to approximately 58,000 people (Figure 1).

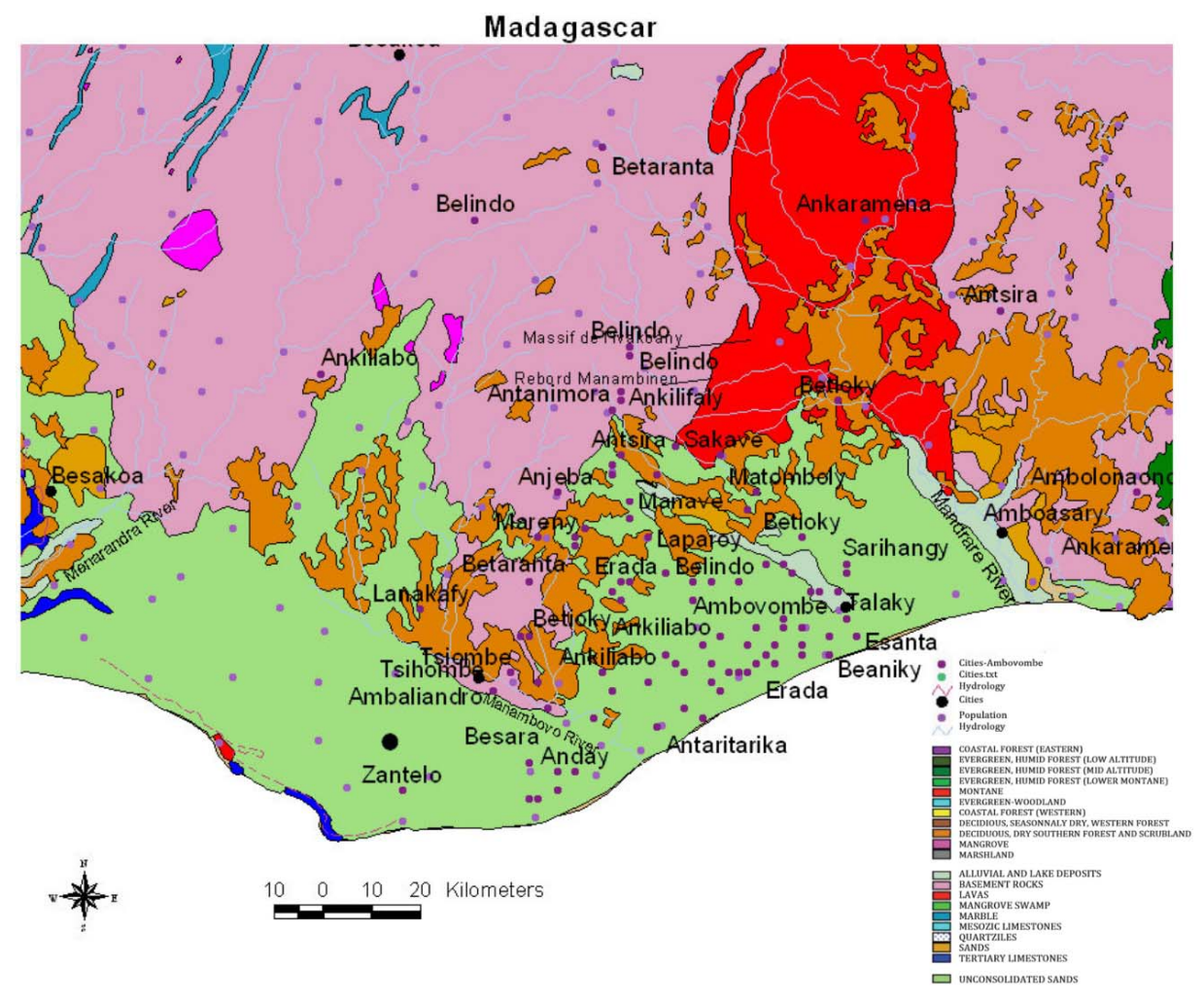

Figure 1. Soils in Ambovombe Madagascar. 
Madagascar might be best known for its rainforests, but climatically it is a very diverse country. Ambovombe gets between 300 and $400 \mathrm{~mm}$ of rain per year making it semi-arid. Nearly all of this rain comes at once in a highly unpredictable pattern. The semi-arid zone borders an arid coastal zone to the west and a humid zone that includes rainforest to the east. This somewhat unusual occurrence is due a volcanic mountain ridge along the Ambovombe east border (see Figure 2). To the east of the Mandrare River is an area that, with significant irrigation, can sustain regular cultivation. To the west of the Mandrare there is a hydrologically closed basin that makes up the majority of Ambovombe.

The great majority of the population is of the Antandroy ethnic group. This is a loose grouping of clan and kin groups that speak the same dialect of Madagascar and share the same history. The Antandroy people have historically lived on pastoralism. Without a regularized water source agriculture was rare. It was introduced by the
French. Villages such as Ebelo, Miary, Babaria, Esira, and Berohanga all became rice bowls for the colonial administration in the city of Tolagnaro to the east. Most of this area is part of the Amboasary prefecture. Such efforts were not made in the Ambovombe prefecture, but as the Mandrare alluvial extends into Ambovombe, some villages, such as Ebelo, fall within the prefecture (see Figure 2) [13]. Ambovombe town then grew to include an agricultural market. Further, an area agricultural taxation stimulated farming even into the basin.

Systemically, water crises have disproportionately impacted women. In Ambovombe more than 75 percent of the time it is women who are collecting water. In fact, women spend more time collecting water in Ambovombe then anywhere else in the country-more than an hour every day. Women heads of household are rare and nearly one in four women live in polygamous households [7]. Women have lower literacy rates and worse nutrition [14].

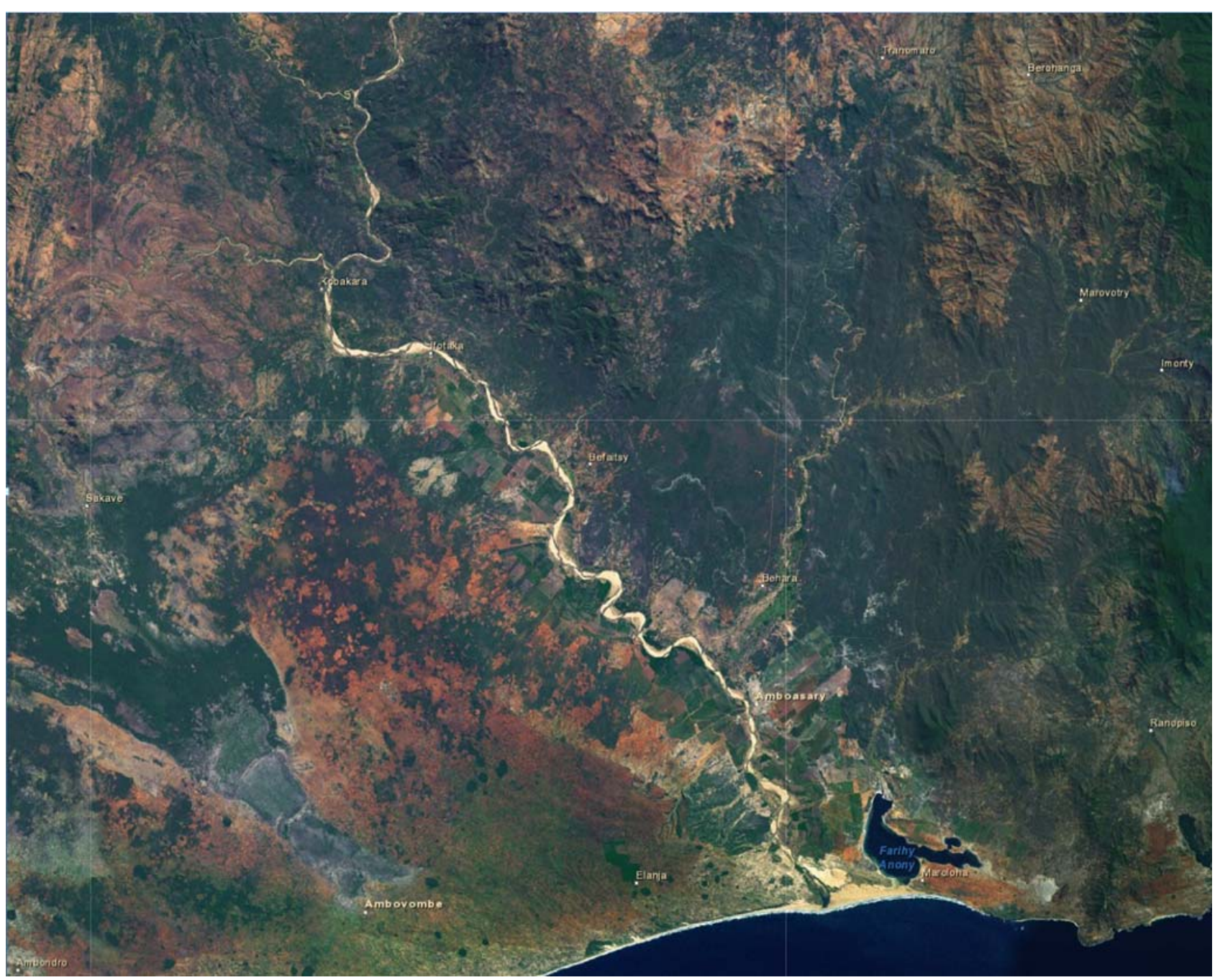

Figure 2. Mandrare alluvial limits. 
In Ambovombe women commonly have little say about who they marry. Once married, both extramarital relations and divorce are forbidden of women. This holds even if the man is away for an extended period or if his whereabouts are unknown. If a man divorces a woman then she most commonly returns to her father's family; she is not allowed to remarry without the permission of her husband (though relations are often good between a woman and her former husband). Children generally stay with their father or, in the case that the children have been distributed to other family members, with them. A woman's right to see her children is held their father [15]. Antandroy customs forsake the idea of inheritance. Thus when a man dies his home is burned and his cattle are slaughtered. His wife and children must distribute the meat without accepting any for themselves. Women are not afforded leadership roles among the fokonolona (community), and are rarely afforded leadership roles in the fokontany (most local official administrative unit) or other, higher, administrative units. Today there are some shifts in these rather rigid roles for women as well as the role of inheritance. Yet, women still hold a subservient position. Efforts to improve the role of women in water resource decision-making (consistent with the global policy norms established in the such charters as Agenda 21, the Dublin Accords, and the Second and Third World Water Forums in the Hague and Kyoto) are thus met with stiff resistance in Ambovombe. Women may be most affected by decisions about water for household consumption, they have the least say in the process.

\subsection{The State, the World Bank, and Ailimentation en Eau dans le Sud (AEP)}

Madagascar's water sector is one in a state of flux. There really was very little effort in water resource management or investment before the mid-1990s. Most efforts that were made came from the state level as the state saw its role as one that takes the lead in national development. This is changing. The decentralization of the Malagasy political system has come parallel to the growth of global norms in water management that reify community participation in the management process. The policy fit is snug as the state can ultimately divest greater water development responsibilities to communities.

At the state level the entity with ultimate responsibility for water delivery is Ministry of Energy and Mines. It must coordinate with the Ministry of Water and Forest responsible for surface water management, and the Ministry of Health responsible for assuring potable water. The Ministry of Energy and Mines is organized into four relevant departments: The most critical herein in the Department of Water Exploitation. The Alimentation en Eau dans le Sud (AES) operates exclusively in the south of the country. It was created by presidential décret 86 - 241 in August 1986 with the idea of organizing statutes for water management in the south. It is the only public water supply interest in the region. The Autonomous Service for the Maintenance of the City of Antananarivo (SAMVA), and the Sanitation Service (SAGS), coordinated with the Ministry of Health.

As of 2002 the Minister of Energy and Mines envisioned preparing a document on the Politics of Development of the Sector of Potable Water Supply and Sanitation in the Rural Sector (PD-AEPAR). This document is intended to address several key themes leading to policy resolutions for certain key questions. What are the conditions for decentralization of the process to take and execute decisions? What are the finance mechanisms? And, what is the role of private sector participation in the development program?

This document has yet to emerge. As a result, these questions are still left unanswered and these key areas of water governance are still being decided on an ad-hoc basis. Institutionally, there has been an independent government body set up, the National Water and Sanitation Authority (l'AutoritéNationale de l'Eau et de l'Assainissement, ANES). Yet without understanding the above issues, it as of yet lacks capacity to perform basic administrative functions let alone improve infrastructure, set up pricing mechanisms, and establish a sustainable system of resource governance. Even as it becomes more effective, its first goals are to focus on organizational reform of the drinking water supply, set up a sanitation sector, and ensure environmental protection. There is no provision for agricultural water for the subsistence farming population.

This appears to be the theme. All current major water policy reforms in Madagascar address drinking water supply and sanitation. Indeed, the Water Code itself presents, in Article 1, its priorities as:

- The public domain of water.

- The management, the conservation, and the assigning of value to water.

- The organization of a public service for drinking water and collective domestic water use sanitation.

- Water policy.

- Financing the water and sanitation sector.

- Organizing the water and sanitation sector.

Public drinking water supply and sanitation is critical to be sure. However, nowhere does this address agricultural use; this is a peculiar omission for a country whose population is majority agrarian and whose economy is primarily agricultural. The agricultural and pastoral sectors are completely omitted from the primary goals of the document. Chapter 3, Section 1 of the Water Code does ultimately address irrigation needs. Yet even this section merely describes the process of obtaining irrigation rights 
(via the National Water and Sanitation Authority) and not anything about management, organization, policy, or financing of water for agricultural purposes.

Agricultural water policy that does exist is not well codified, but it does have certain objectives. These are to maintain irrigation infrastructure, reduce the state contribution to irrigation, help the state disengage from the management and maintenance of irrigation, and increase infrastructure investments from rural users. It intends to do this by establishing community level water users association and giving management responsibilities to those associations [16].

At the project level agricultural policy has meant very little. The focus has been almost entirely on household consumption. Such projects began in Ambovombe in the 1980s under state water supply projects with World Bank financing. They were few and with limited scope. In the 1990s these projects were replaced by donor-supported projects run by international non-government organizations and, in the south, the AES (Alimentation en Eau dans le Sud).

The AES is also governed by the Ministry of Energy and Mines. It historically has had an operating budget of approximately 2.48 billion FMG (\$US 388 mill). It is charged only with provisions for potable water in five regions of Madagascar's extreme south. The Department of Water is responsible for all drinking water in Madagascar but does not supplement the AES budget. The provision in the AES budget for investment has historically been nil and remains small. Thus there are no infrastructural improvements or development of new activities. Its sole purpose historically has been is to support private water markets to offer water at a more competitive rate [17]. In 2011 approximately 34 percent of the budget went to water network support but the budget had fallen to $\$ 4.3$ million [18].

In 1995 there was a large information and education effort undertaken by the AES. This was in preparation for its new effort to provide water from the pump. The associated new policy was that the responsibility of managing water would be transferred to the five centers (one in each of the regions where the AES operates). It became the job of communities served by the AES to collect the water funds from water users based on volume. The community could add a surcharge to pay for pumps and other equipment. The efforts of the AES have not been very successful $[16,19]$.

The majority of funds have been spent in urban areas with only a small fraction of the funds going to the extreme south. Moreover, like the AES, the approach has generally not been very sustainable. In the case of the Ambovombe investment has been minimal. By the end of 2004, 202 boreholes and pumps will be installed, along with 90 community-level water users committees, but no significant augmentation in water infrastructure accompanies it $[17,20]$.

This is indicative of a regional development bias. Though the most grave water crisis is in the south of the country, Ambovombe, and the entire Toliara province, the investment is significantly lower than in the capital. There are 42 gravity-fed water sources in the province of Toliara, compared to 724 in the capital province of Antananarivo. Between 1997 to 2000 gravity-fed water sources increased by 5 percent in Toliara province and 30 percent in Antananarivo. In total, there is one gravity or pumped water facility for every 515 people living in rural areas of Anatananarivo province and every 3376 people in rural areas of Toliara province [21]. Irrigation infrastructure is scant as are surface water diversions for agriculture and boreholes for agricultural use.

The UN Food and Agriculture Organization (FAO) points at three reasons for the failure of the AES and investments; in order:

1) A deficient institutional organization.

2) A high level of reoccurring costs of certain types of hydro-agricultural systems.

3) The politics of agricultural price incentives.

Our preliminary investigation indicates that local perception may be that the problem is not so much institutional governance as a problem of level of investment. Comparing the infrastructure investments in Madagascar to what is perceived of as "necessary" for sustainable water management in other parts of the world leads to concern. However, our larger concern is that there appears to be little community knowledge of how the broader water system works or what the institutional organization is, even by community and sub-prefect leadership. Where by design the community is supposed to "participate" in the process, this would seem a grave problem. If this conclusion holds on further probing then it means that the implementation of the system (as opposed to institutional organization) is a dramatic problem, there is a disjuncture between system design type and community (end-user) desire, or both.

This lack of investment contributes to a feeling that government is rarely seen or felt in the region other than at times of herd tax collection. As a result, people live much of their lives beyond the regulation or service of the state, or even knowledge of what it is that the government is doing. As one local farmer put it:

The government doesn't do its job. We don't know really who is setting this law around here, but we know that the forest and water is part of the continent. We don't know if it is [the National Park Service] who sets the law; we don't know if it is the [National Park Service] or that [Department of Water and Forest] who sets this law. We are harvesters, and we live on farming. 


\subsection{Decentralized Units}

As mentioned above, the primary points of Madagascar's 1998 Water Code were that water should be universal, well-managed, and commodified. Coming on the heels of state decentralization, this is interpreted as requiring community (commune-level) level management of water resources. Cost recovery was codified as a part of financing existing water services and hoped-for improvements; new community associations have become responsible for ensuring that these terms are met.

Mark W. Rosegrant, Ximing Cai, and Sarah A. Cline [22] discuss this approach in a global context. They note: In the water sector, the management of river basin and irrigation water would become more efficient, but slowly. Governments would continue to transfer management of irrigation systems to farmer organizations and water-user associations. Such transfers would increase water efficiency if they are built upon existing patterns of cooperation and backed by a supportive policy and legal environment. But these conditions are often lacking.

Madagascar suffers from these sorts of deficiencies. First, the community often doesn't have the expertise to go about proper governance and technical advisors are spread too thin. Second, new community organizations are created alongside community organizations for environmental conservation purposes and community development organizations. None of these organizations necessarily hold the same leadership as one another let alone the elected official leadership or "traditional" leaders. They also often operate outside of existing community groups and, particularly in the south, existing dina (community level rules). People are savvy. They do differentiate between associations created by the community and associations created from outside the community [23]. They are often referred to as such (Kull 2000) and sanctions are often not particularly serious against violators of foreign dina. This is especially true where there is conflict between a new dina for resource governance created from the outside and an existing common law dina. It has often been the case that the competing associations set up crises of authority. Whom one goes to resolve an issue can vary dramatically by the nature of the problem. In theory, if the conflict is over land use then the environment association (the Community de Base or COBA) is responsible; if the conflict is over water then the water association is responsible. The role of the PCLS (most local official unit of government) and the mayor (commune-level) is painfully unclear.

While the Code applies to the entire citizenry, in practice this policy change affects the majority rural sector in disproportionate ways. In Madagascar the rural sector relies primarily on subsistence agriculture, often beyond an adequate cash economy. This brings out another problem. As characterized by Isabelle Droy [24], liber- alization in Madagascar has been problematic because it has been accompanied by a disengagement of the state and a transfer of resources to local user associations. Since communities lack the capacity to undertake water sector reform with limited state funding or involvement, it often fails. What replaces is, essentially, a process of rural sector water commercialization. Early experiments in this process, such as those in the Antsirabe region Droy examines, have proliferated to become the normative practice codified in national law and supported by international donors. In Ambovombe private water delivery is not quite as codified, but in the wake of limited infrastructure, it is a primary source of water for many households throughout the starving season.

To overcome the capacity problem in the agricultural sector, the intent of Madagascar's new system is for efficient water users associations (the decentralized collectivity) to work with officials to design an irrigation system. These associations work in similar fashion to water associations for drinking water governance, emphasizing diminished or eliminated state investment. The cost of construction would be determined and paid for by the participants in the system through the assessment of a per hectare irrigation charge. Ultimately, water metering would allow the water district to charge for water consumption as well as infrastructure. Such an approach is not uncommon in the United States and elsewhere. The logic is that the cost of water is assessed, waste is discouraged, and sustainable use encouraged. In Madagascar the system is intended to achieve complete cost-recovery not ensure access.

\subsection{Water and the Environment}

The Spiny Forest Ecoregion in the far south is included in WWF's “Global 200”, the land and water environments that are among the ecologically richest, rarest, and most endangered on the planet. This has made the region a center for sustainable development and internationallyfunded multilevel management efforts. The environment suffers from high population growth rates, significant immigration, and the impact of high poverty and gender inequality. It is also a semi-arid region, with arid variances. All of these issues are cardinal in Madagascar's 1988 National Environmental Action Plan. However, there is virtually no existing link between the Environment Programs that have emanated from the Environmental Action Plan and water management. In fact, the relative dearth of hydrological studies, let alone ecological systems analysis or conjunctive water use studies, would lead us to believe that groundwater exploitation is virtually blind water mining. It thus appears that new water management system attempts are working across environmental conservation purposes. 


\subsection{The Economics of Water in Madagascar}

Cost Recovery. The idea is that only by paying the true cost of water can sustainability be achieved. Water infrastructure should be a further community expense. Preliminary evidence suggests that in rural areas people are averse to paying for water at all [20]. There are two problems at work. The first is, consistent with work conducted by the author in neighboring Anosy, that people feel it is the government's job to provide basic services such as drinking water, irrigation, and the related infrastructure. They shouldn't have to pay. The second is practical. Families earning less than $\$ 400$ per year cannot afford to pay the recovery cost. In the US the average cost of water is approximately $\$ 0.52 / \mathrm{cm}$. Farmers are subsidized and pay rates ranging from zero to about $\$ 0.10 / \mathrm{cm}$. In Madagascar private water suppliers charge about 13,650 FMG/cm (\$2.16). The “subsidized” AES project water charges $6666 \mathrm{FMG} / \mathrm{cm}$ (\$1.06). While local populations may be willing to pay for water (Marcus 2007, [20]) full cost-recovery is challenged by the local population and shouldn't be surprising given the relationship between the rates and incomes. The private rate is approximately $\$ U S 2.16 / \mathrm{cm}$ and the AES rate is approximately $\$ 1.06 / \mathrm{cm}$ excluding a provision for sustainability. This is substantially higher, in real terms, than average rates in wealthy American and European markets including water coming from recovery or desalination plants with private full cost-recovery models.

The problem with pricing is the supply time and consistency. Bhatia and [25] discuss an important relationship between water supply type. In a study of 17 locales in the developing world they find that water prices charged by such water vendors ranges between 5 times and 83 times the public utility cost of water. In this way it is a catch-22. Poverty and low levels of development leads to a lack of infrastructure investment, but the lack of infrastructure leads to unsustainably high prices that reflect a service cost not the resource cost.

In Ambovombe there is no master plan. There is no attempt to link large-scale water development investments to bring about development. Rather, the investment is in drinking water sources to reduce human suffering. While meeting basic human needs is both noble and critical, infrastructure is virtually non-existent. Without a provision for infrastructure it is possible to implement poverty alleviation measures but it is not possible to seek development.

Boreholes in southern Madagascar cost an average of US\$ 9600 each plus a pump. Gravity systems cost an average of $\$ 17,220$. These investments do help particular communities increase access to safe drinking water. But at what cost? It is a short-term solution with long term impacts for community survival and the viability of groundwater resources in the closed basin.

\section{What Is Israel Doing?}

If the primary goal of water management is to ensure that individuals have their basic right to water met for both the near and long term then it would seem to eschew the argument for (profit-motivated) water privatization in favor of a (non-profit motivated) national water system that can equilibrate pricing, mandate proper resource management, and ensure that all citizens have access to clean water. Perhaps the best model for such a system has historically been the Israeli National Water Carrier.

The Water Measuring Law of 1955 mandates that all water distributed in Israel must first be measured. This law, adopted seven years after the declaration of statehood, set Israel apart from countries following English Common Law or variant riparian water doctrines as well as countries like Madagascar where water law is sparse on rights and ownership. While the 1955 Measuring Law upheld private water rights, the seminal 1959 Water Law made all sources of water the property of the people under the protection of the government. Article 1.9 articulates a distinction between the right to land ownership and the right to the water which flows on or below it. "The water resources in the State are public property; they are subject to the control of the State and are destined for the requirements of its inhabitants and for the development of the country A person's right in any land does not confer on him a right in a water resource situated therein or crossing it or abutting thereon" [26]. Water sources are defined broadly in the 1959 law (Article 2) as "springs, streams, rivers, lakes, and other currents and accumulations of water, whether above ground or underground, whether natural, controlled, or man made, and whether water rises, flows or stands therein at all times or intermittently, and includes drainage water and sewage water”. Israeli water law today is still based on 1959 law. Its breadth has given the state the authority to reclaim water from urban gray water supply, build a national water carrier, standardize pricing, and grow desalination plants.

Authority in the water sector is divided between ministries. The Ministry of Agriculture is to "Prescribe norms for the quantity, quality, price, conditions of supply and use of water and rules for the efficient and economic utilization of water" Establish regulations concerning "protective strips" around water resources, "for the purpose of preserving any water, water source, water works or any installation for the extraction, storage or conveyance of water entry to and passage through which shall be prohibited except under a permit from the Water Commissioner”, and ration water as necessary. The Ministry of the Environment is to "Promulgate regulations, in coordination with other government ministers, to prevent the pollution of water resources” [26]. 
The Water Commissioner, appointed by the Government, has the responsibility to enforce the Water Law and Water Regulations, and to maintain water quality. As stated in the law [27]:

Where the Water Commissioner appointed under section 138 (hereinafter referred to as "the Water Commissioner") is satisfied that any of the provisions of section 9 is not being complied with, he may: 1) Order the person bound to comply with the provision to rectify the situation in accordance with the order and, if the situation is not rectified within a reasonable time, do whatever necessary to rectify it and order the discontinuance or restriction of the production, supply or consumption of water, as the circumstances may require, pending rectification of the situation. 2) Take steps to prevent immediate serious damage to a water resource if such damage cannot be prevented in any other way. The Water Commissioner may, by order, charge expenditure incurred by him for the purposes of action under Section 11 to the person who was bound to comply with the provisions of Section 9, and upon his doing so such expenditure shall be recovered as if it were a tax to which the Taxes (Collection) Ordinance, except Section 12 thereof, applies.

The Water Commissioner was, until the mid-1990s, within the Ministry of Agriculture. He is now in the Ministry of Infrastructure. As a balance of power mechanism, his budget is subject to review by the Knesset. A recommendation to fund is made to the Ministry of Finance who ultimately must decide.

Israel's problem, like Madagascar's, is that there are sufficient water resources in the north but not in the south. Approximately 38 percent of the country's water comes from Lake Kinneret, another 38 percent from the Coastal and Mountain aquifers, and the remainder from additional sources (including high technologies such as water desalinization and renewal). Unlike Madagascar, Mekorot manages a 175 mile long pipeline moving water from the north to the south where it has famously "made the desert bloom" with agriculture. Manufactured water is produced through public-private partnerships (mostly Build-Operate-Transfer) but with few exceptions only Mekerot has the right to purchase the water and once it enters the national carrier it becomes part of the public supply.

There have been significant challenges to Israel's state-centric approach. The negotiated transition to an increased role for municipalities and local providers within a broader state umbrella has not always been smooth [28]. Water pricing, while carefully state managed for equity, has inadvertently created imbalances across regions, demographies, and end-user groups, while struggling to factor the scarcity cost [29]. The nature of the shifts in Israeli water policy (beginning in 2006) did not successfully address the fragmentation of the water policy environment [30]. The most significant challenge over the long term has been that fragmentation grows interest groups and such groups have remained central to Israel's water system. Legally, agricultural interests are secondary water consumers. Yet, historically the linkage between Zionist nationalism and agricultural production has led to agricultural domination in water decision-making. This is why historically the Water Commissioner was originally in the Ministry of Agriculture, not the Ministry of Infrastructure. In an extreme example of this, one of the consequences has been that water allotments have come to be regarded as entitlements for farmers. When they are cut back in years of drought, farmers are granted "compensation" for the water they do not purchase. Where there is a crisis, agriculture is the first to have its water shut off. However, such shut offs are temporary-usually lasting only a few hours.

Water politics, like most politics in Israel, is highly personalized. The power to affect change is largely vested in the individual in the position rather than the position of authority itself. At minimum, effective governance or getting things done requires a persuasive personality and a well-connected individual. Many agreements are made outside of primary channels. In the water sector this has led to certain distortions. While everyone has known for nearly three decades that the system is failing, political interests, especially those closely tied to agriculture, have superseded effective water management decision-making. The former, and longtime, Water Commissioner, Meir ben Meir, describes this position of these powerful agricultural interests well (personal communication):

Water and land policy must be comprehensive. They can't be separated as some economists are trying. The arable land area in Israel is shrinking while the population is growing. That is the problem-not the amount of water. There must be water to ensure there is arable land.

Effective water "management" is challenged by the politics of water management. Kislev [8] notes the tremendous institutional gains made in Israeli water governance, pointing to state of the art water treatment plants, limitation on the supply side of potable water for agricultural purposes in favor of water designated for agricultural use, and water corporations under local authorities. However, he argues, transparency in governance remains elusive. Technical expertise is high but much decision-making is made by political, not technical, appointees. Full information is not a legal requisite. Council meetings, decisions on investment and cost-benefit analysis, rate determination criteria, financial reports and financial report timing, all remain opaque while managers in the Water Authority can legally conceal informa- 
tion. There is limited public involvement in water governance and little public discussion. Kislev [8] supports the 201 Bain Commission finding that an independent Public Council, with an independent budget and right to publish, would help resolve this information gap. Instead what we see is a lobby for water with the Chairman of the Knesset State Control Committee at its head. This will not serve to extricate technical decision-making in the policy realm from politics.

\subsection{Institutional Change}

The system worked well until the 1970s. Today the problem is water supply. Agricultural still uses nearly 70 percent of the water supply but its needs have actually even flagged slightly. However, sum water needs have increased with significant population growth (largely from immigration), responsibilities under international agreements, industrialization, and, most of all, improved standards of living associated with rapid development. Following the policy of personalized water politics, the problem was virtually ignored. As a result, the primary water source, the Kinneret, has been mined for more than 20 years, progressively lowering its total capacity output.

In 2002 Israel's water stood $500 \mathrm{mcm}$ below its red line. (State of Israel 2002) The overall water deficit hit a low of a staggering $4200 \mathrm{mcm} /$ year. As Figure 3 illustrates, there has been bouncing in natural source supply by it continues to be a challenge. Pollution, in particular Chloride, is an increasing problem. The once idealized story of state-led water sector growth in Israel has given way to unsustainable water use marred by mismanagement and political infighting.
Israel has started taking significant steps to ameliorate the situation. It has become a leader in renewable water technologies, treating the bulk of Tel Aviv's sewage and carrying it south for irrigation. Israel has seen desalination as the answer. A plant built in Ashkelon was, when it came on line in 2004, the most advanced desalination plant in the world. The Eilat-Ashkelon Pipeline Corporation (a consortium of IDE Technologies Ltd., Vivendi Water S.A., and DanknerEllern Infrastructures Ltd.) guaranteed that for 25 years it would supply Mekorot with 100 million $\mathrm{cm}$ of water per year at a cost of $\$ 0.53 / \mathrm{m}^{3}$ - the lowest cost of any such plant. The energy comes from (local) national gas suppliers; it complies with rigid environmental monitoring standards including water temperature impacts. By the end of the decade Israel manufactured water to yield over $400 \mathrm{mcm}$, more than half of the Kinneret's production. The Water Authority predicts that with the new $100 \mathrm{mcm}$ desalination plant in Ashdod scheduled to come on line in 2013, Israel will manufacture nearly three-quarters of its drinking water at a cost ranging from $\$ 0.53 / \mathrm{m}^{3}$ to $\$ 0.67 / \mathrm{m}^{3}$ (well below freshwater in many markets) ${ }^{5}$.

1) Economists and managers argue, however, that, while critical, technology itself is not enough. There must be a significant change in water policy. Specifically, the goal must be to separate water and land policy in order to charge the real cost of water. From this perspective [33], necessary changes in the water sector have been hampered by agricultural interests. There must be extraction levies. There needs to be institutional reform that allows for more transparency in the governance process than the Water Commissioner making a decision behind

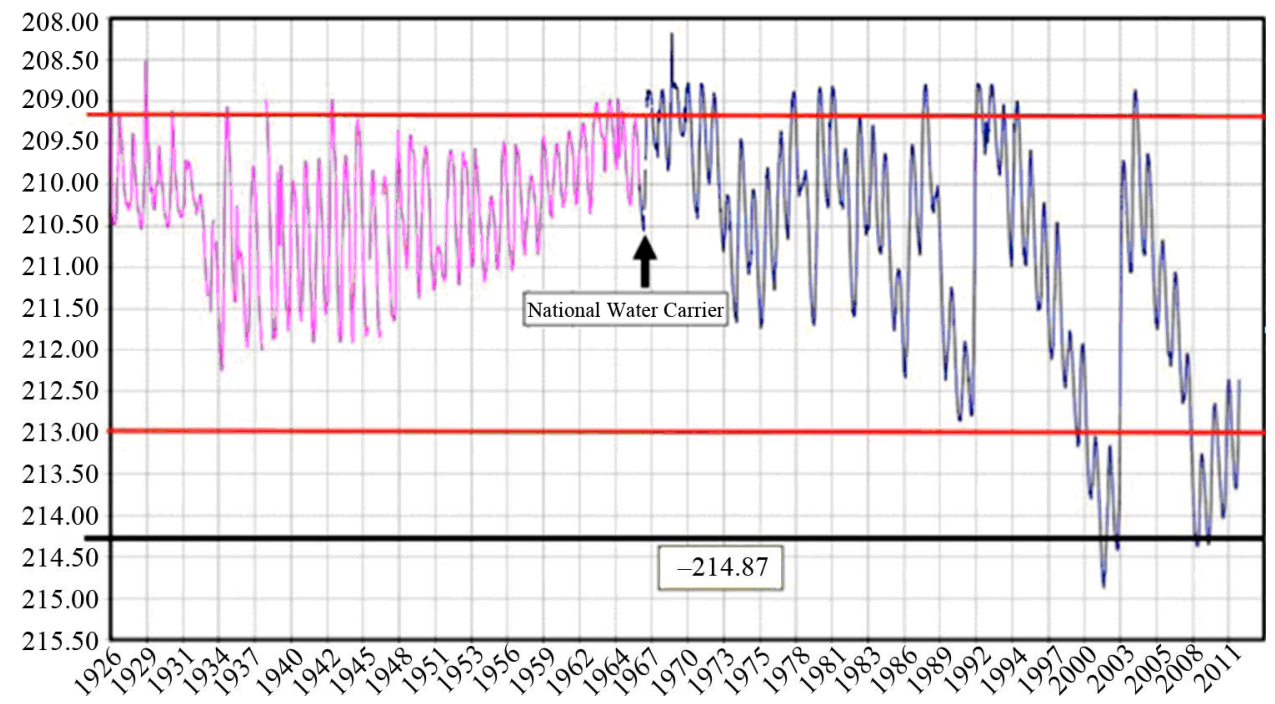

Figure 3. Water level of the Kinneret (in meters by year) [31].

\footnotetext{
${ }^{5}$ Becker et al. [32] argue that these figures do not take into account environmental, land, marine, salinity impacts on crop yield, and the like. They point to $\$ 0.065 / \mathrm{m}^{3}$ in external costs not factored here. While a significant hidden subsidy, even with this factor the cost of desalinated water in Israel is lower than freshwater in many countries.
} 
closed doors or the Minister of Finance funding or not funding a project without comment. Management itself must also be improved budgeting needs to be both more transparent and improved. All of this is seen as part of a systemic problem in Israeli governance that there is no intergenerational thinking in the budget or management process. From this perspective, agriculture can be maintained outside of land policy by letting it evolve. It is already happening. Nearly all farms are run by (Jewish) Israelis, but staffed by laborers from Thailand or other (mostly Asian) countries. This enables agriculture to be more internationally competitive.

2) Further to this economic position, there is a perceived gap between power and authority. Farmers fight in the Supreme Court and the Knesset against extraction fees, price increases, etc. and they often win. But, it is supposed to be the Water Commissioner who decides. The Water Commission is only as strong as the Water Commissioner and when he is weak, agricultural interests are able to end-run around him. This is a common complaint about the current Water Commissioner, Shimon Tal. He stands accused of not understanding extraction fees, and other key mechanisms, so he shies away from making any decision about them. If the courts are to ask the government "how do you decide on the fee?" it won't be able to reply. The system is one of personalized, not well institutionalized, policymaking.

3) This is, in fact, the heart of the changes in the late 2000s. In June 2002 the Knesset completed a ministeriallevel study, releasing a report entitled The Parliamentary Committee of Inquiry on the Israeli Water Sector. The Committee concluded that "in light of the knowledge available to experts in Israel and abroad, an efficient and responsible management of the water sector could have prevented the crisis, by finding creative solutions to all the problems. The eyes of those responsible for the water sector in the various Governments, failed to take note of the dangers, and when they did see them-they failed to act. They go on to side with economists and practitioners, against long-seeded political interests, to call for the institutionalization of water management norms of governance. Specifically, they call for emergency powers to be granted to the Water Commissioner in the short term, and the following 10 reforms to be created in the long term:

1) Reduce the multiplicity of bodies dealing with the water sector.

2) Abolish the administrative involvement of the Government in the allocation of water and its uses. The only link to the Government shall be by means of the Minister for National Infrastructures, and in times of emergency, by means of the Prime Minister.

3) The role and authority of every Ministry connected to the water sector, shall be defined by law.
4) The Water Commission shall turn into an independent and professional authority, which will not be within the framework of any Ministry. The role of the Authority shall be to manage, settle and direct the water sector on the national and regional level, in accordance with up-to-date instructions in the Water Authority Law, the Government's policy, and the recommendations of the Water Council.

5) The Water Commissioner shall be selected by the Government, on the basis of the recommendation of the Minister for National Infrastructures, and the Commissioner shall be a professional in the sphere of water.

6) The powers of the Water Commissioner shall be the overall responsibility for the availability of water for the whole population, the preservation of natural water resources, the planning and development of water resources, and the fixing the annual production quotas for all the natural water resources. The Water Commissioner shall settle the issue of supply.

7) Within the framework of the Water Commission or the Water Authority, a body shall be set up that will be responsible for the publication of, as far as possible, full, agreed and updated data, in all spheres of the water sector.

8) The number of members in the Water Council shall be reduced significantly, and its make-up shall be changed, so that the Council will include experts and professsionals side by side with representatives of the Government and representatives of the consumers and producers.

9) A statutory professional committee for the pricing of water, shall be set up.

10) Supply areas shall be determined.

The power the Knesset grants the Water Commissioner is beyond what many economists and practitioners feel comfortable with. As one notable economist has commented, why would we want the Water Commissioner to do the Minister of Environment's job? However, the institutionalization and regularization of hitherto personalized norms is welcomed. Further, it is recognized for the pivotal work that it is. Much of the Committee was comprised of ministers with agricultural sector ties, most notably Abu Villan the former head of the agricultural lobby. They are effectively diminishing their own authority in the name of improved resource governance. As David Magen, the head of the Committee, declares in the introduction to the report, "We did not seek "blood"-we sought water!” And so it seems.

In a similar measure, the Israeli Water Authority released, in June 2002, its Master Plan for water reform 2002-2010. It complimented the parliamentary policy directive by seeking to "to outline a framework for development and rehabilitation of the water supply sector by the end of the decade." It outlined a significant "de- 
velopment plan” with steadfast goals for ensuring that Israel avoids water crisis for the next decade. Further, it works to professionalize a system of rational water management that is sustainable for the long term.

Working from water user needs out, the plan determined that the (fairly stable) agriculture sector needed to be guaranteed $530 \mathrm{mcm}$ of water per year-a figure derived from actual consumption figures. That, not the political linkage between land and water or the posture of the agricultural sector, becomes the sacred cow. It then goes on to model the needs of other end users and creates a system of supply augmentation and multiple use water schemes to meet that supply.

For the first time in Israeli history, environmental water needs began to be considered. In consultation with the head of research for Israel's national park service, it determined that most needs can be met by considering the environment an end user and allocating $50 \mathrm{mcm}$ per year. The remainder of environmental needs can be met through multi-use management systems. The cost of this project, all said, is 19.9 billion NIS (US\$4.52 billion) with about 9.1 billion (US\$2.07 billion) of this to come from private sources.

In 2011 the Israeli Water Authority began work on a new Master Plan. Whereas the 2002-2010 Water Master Plan was a critical step in both institutional development and disaggregating political influence from a technical process, the first concern being addressed in the new draft plan is water governance-institutional structures, division of responsibility and authority, the process of decision-making, personnel, enforcement, and barriers. In a continuation of the earlier plans dedication to environmental water needs restoration and preservations of water resources and ecosystems is also noted as a key challenge. To address these challenges the primary objectives of the plan include updating policy formulation in key issue areas, assessing the distribution of power by the Water Authority, estimating activity under conditions of uncertainty, building a framework for integration and coordination among all programs and stakeholders, and creating a new water management planning infrastructure.

\subsection{The Role of the Private Sector}

Israel has a welfare state history. As such, the 1959 Water Law made no provision for a private sector role. All water belonged to the state, and all water management and distribution responsibilities fell to the state to ensure equitable resource management. To this end, no one but the state could pump water from surface or groundwater sources with hard-won, and generally very limited, rights from the state. The private sector was limited to these few agricultural interests pumping water for themselves and selling back to the state in small quantities ${ }^{6}$, concessions for high end bottled water, and delivery facilities for unrecognized Bedouin populations (in which case the water was purchased from Mekorot).

In July 2001 the Water and Sewage Corporations Law was passed. This was a landmark change in the role of the private sector in the Israeli water sector. Under this law municipalities became responsible for providing and managing water for their constituents. This was already de facto in place. However, now these municipalities are "allowed to decide that certain essential functions that are under its responsibility will be done by a corporation that will be built for this purpose if a local municipality hasn't decided to build such a corporation within 3 years from the day the law is issued, the Minister of the Interior and the Finance Minister (with the permission of the economical committee of the Knesset) can command the municipality to build a Water \& Sewerage Corporation, and transfer the operation of the water and sewerage system to its hands" [34]. These corporations can be public or private at the decision of the municipality.

This law (modified in 2006) changes the nature of Israeli water law. The state continues to own the water in trust for its people, and water can only be purchased from the (parastatal) Mekorot. However, municipalities can now enter into public-private partnerships for the privatization of virtually all water services from infrastructure to collections.

In example, Gichon is Jerusalem's water corporation and as such provides water for 10 percent of the country's population. Gichon buys water from Mekorot, distributes it to its constituents, and then sells the excess and purified sewage back to Mekorot. Since 2001 Gichon has issues a number of private tenders, most notably to Ness Technologies which has invested NIS 50 million (US $\$ 11.3$ mill) in data management and the sewage system. Gichon itself was put out for tender. It expects to sell 50 percent of the company to raise $\$ 150$ million.

It is a very attractive proposition ${ }^{7}$. The corporation

${ }^{6}$ The exception is in Jerusalem where 40 percent of pumping is private. In 1999 these private pumpers started paying. A 1999 Supreme Court ruling stated the Water Commissioner can force Mekorot to allow private pumpers to sell water to the National Carrier or use the system for transporting the water to a municipality to sell it. In total it is about $50 \mathrm{mcm}$ - not a negligible amount. Pricing is set by Mekorot as part of its constant pricing mechanism.

${ }^{7}$ This analysis is purely economic. There are a host of political, religious, and security concerns that surround the privatization of Gichon. The word itself means "bursting forth" and is the name of Jerusalem's underground spring that serves as a primary water source. The spring is cited in the bible, Chronicles Book 2 32.30: "This same Hezekiah also stopped the upper spring of the waters of Gihon and brought them straight down on the west side of the City of David.” (Other references exist throughout the story of the battle with the Assyrians). Around 700 BCE King Hezekia built a tunnel to the spring because it was outside the walls of Jerusalem. This is used as evidence today that the spring itself doesn't belong to Israel but rather the Palestinian population. Its sale to the benefit of Israel thus has significant regional ramifications that are left unaddressed by the water plan. 
made all necessary major infrastructure investments before putting it out to bid. They raised the money under the 2001 law by raising rates (the options would have been to float a bond or a new tax). Consumers are thus likely to see a decrease in the water unit cost under privatization. As a result, there is strong public support. Jerusalem will raise nearly all of the money it needs for its new light rail system and have \$50 million left over. Gichon will likely see an increase in efficiency of management. The new Water Authority will ensure it doesn't run amuck to the cost of its users. It appears to be a winwin for all sides.

Israel's largest agricultural sector are still moshavim. These collective farming units have historically had a tremendous sway in water legislation and policymaking. Moshavim themselves are generally public entities (though there have been some moshav privatizations). They are occasionally granted rights to pump groundwater, but generally purchase water directly from Mekorot (not through the municipality). Under Israel's new plan significant price incentives will encourage farmers to use reclaimed water for irrigation. The transaction is public-public (Mekorot-moshav), but the company operating the reclamation is private.

Reclamation companies are only of the sources of private water supply in Israel. Desalination plants are private as our water imports. As the percentage of water supply that come from these alternative sources rises, Israel is effectively privatizing a part of its water system. However, all water supply companies must sell their water to Mekorot for distribution, not to third party interests. If the state of Israel does not need the full supply then the company is granted the right to sell the remaining supply to non-Israeli interests.

Israel's privatization is not universal. Mekorot has floated bonds for funding, but it is not slated for privatization. Moreover, it has increased rather than decreased oversight during the decentralization process. As part of the 2001 law a new position of Public Utility Commissioner is being created. Modeled on a similar position in the electricity sector, this Commissioner sets both price and quality. As written, he is charged with:

1) Setting the service standards that the corporations will have to give \& supervising the corporation's duty filling \& caring for consumers complaints.

2) Setting rules for the calculation of the service costs that the corporations will have to provide, as well as rules for fees \& payments.

3) Supervising the corporations costs, \& setting tariffs for each corporation.

4) Setting rules about the obligation to publish \& inform consumers, the public, \& the authority of every action, in order to ensure complete publicity \& transparency of their actions, \& allow supervision of their fulfillment.

5) Counseling the supervisor \& the ministers on issues that they are required to consult the authority about, according to this law.

This is a public, independent position, separate from the government. To date the Ministry of Finance is told how to regulate price by the Knesset. This is the most important change. Rather than the government setting prices this independent professional will. The Commissioner will also regulate the private water market. Effectively, this allows for the privatization of supply and distribution while retaining public capital governing rights. A private Gichon, for instance, is limited in its ability to set supply, delivery, and cost policies. The market is thus trusted to manage, but not ensure equity.

\subsection{Equity}

The legacy of the welfare state has left attempts at introducing equity in the system for all end-users. To date the goal has been to use constant pricing measures to ensure that secondary economic conditions do not disenfranchise parts of the population. Equity has not, however, been achieved to everyone's satisfaction. Farmers pay nearly half of the cost of water as domestic consumers (at the first bloc pricing level). Associated accusations of waste and selling water for profit abound (though new renewable water technologies stand to correct some of this distortion). Further, the cost of water for households, approximately NIS 2.98 (\$0.77) per $\mathrm{cm}$ at first block level, is kept constant across a country through the water commissioner's Equalization Fund. By charging the same amount per unit regardless of location Mekorot assured that all water users could equally afford water regardless of whether they lived in the middle of the Negev Desert or down the road from the Atar Sapir pumping station at the top of the National Carrier. However, unrecognized Bedouin communities, accounting for 12 percent of the Negev region's population, have no water access rights. The seven recognized Bedouin towns, other Arab towns, and even Jewish “development” towns have the right to purchase water at national rates, but without subsidies the income disparity between these users on the one hand and users in established cities and farmers with water subsidies on the other, often puts adequate water resources beyond reach. Further, the political need to ensure particular users have a given access level and price has forced an unsustainable use level of both the primary water sources, the Sea of Galilee, and the two aquifers. Nonetheless, the disparities are a minor component of water issues within Israel and serve to demonstrate how modest they are in comparison to those in Madagascar.

\section{What Can Madagascar Learn from Israel?}

In trying to implement its new water policy there are four 
important things Madagascar can learn from Israel. They include the importance of process, the institutional oversight during decentralization, the approach towards privatization, and the level of infrastructure investment.

\subsection{The Importance of Process}

Israel's process has been of national level debate involving all stakeholders. Agriculturalists and politicians, bureaucrats from across the spectrum, economists and policymakers, environmentalists and private interests, have all had input into the process. It is through this lens that it has become clear that individualized politics will lead to continued water crises and careful management that ensures that agriculturalists get enough water at a reasonable price while ensuring domestic and industrial uses comes to fruition. It is through this lens that environmental concerns and water resource needs are brought together through the establishment of environmental needs as a consumer in and of itself. It is through this process that a vetting process has taken place in which the hydrological balance has been assessed and the science agreed upon, critically, by all concerned parties. In short, Israel's policy plan is a rational summation of needs followed by a plan of action to meet all of those needs to the relative satisfaction of all involved. The only parties left out in the cold are those that seek not to address water concerns, but to address land concerns for political reasons or other issues of geopolitical or religious import.

In contrast, Madagascar's approach has been ad-hoc. The Water Code of 1998 should be able to reflect lessons from Israel's 1959 Water Code and other national water codes from around the world. It should be able to assess problems other countries have faced in implementation, in particular the appeasement of all parties. It hasn't. It has addressed one narrow area of water resource needs. Agricultural water use is beyond the pale in an agrarian country. Industrial water use is beyond the pale in a country seeking to develop. Environmental water use is beyond the pale in a country marked as a biodiversity hot spot. The "science” isn't in debate but not because all agree on it but rather because it isn't known. The hydrological research is limited and what exists is poorly disseminated to policymakers and other interested parties. Communities have not access to it. In Ambovombe in particular where conjunctive studies would help us better understand the relationship between humans and natural resources in a unique ecoregion, the answer to water crisis is not comprehensive, its mining.

Madagascar needs a comprehensive plan of action comparable to Israel's, bringing all parties to the table, do the research to assess everyone's needs, and come up with a plan that meets those needs.

\subsection{Institutional Oversight and the Virtues of Management}

Madagascar and Israel have both been going through a process of decentralizing water management. Whereas in Israel this means a greater role for municipalities, in Ambovombe this means a greater role for rural community associations. There is great reason to doubt that communities have the capacity to take on this role. There is even greater reason to doubt that they should. Community based water resource management may be a globalizing norm (evidenced at each World Water Forum in the past ten years through the Sixth World Water Forum in Marseille 2012), but the empirical basis is weak. As argued above there is in fact evidence that where the necessary preconditions are not in place the ends can be detrimental. At minimum, we need to learn more about what those preconditions are.

As part of its decentralization process Israel is creating new oversight bodies. The system of water governance is being rationalized and institutionalized. The Water Commissioner is being further empowered to carry out his duties independent of the minister he serves, and checks are being put in place to ensure that the person holding that position is a qualified sectoral expert not only a political appointee. Perhaps even more critically, a second oversight body, the Public Utilities Commissioner, is being created. While also a government appointee there is a mandate that the post holder is an economist or closely related professional. He is empowered to set pricing outside of the legislative stronghold and thus beyond powerful, self-seeking lobbies. And, he is empowered to reign in corporations, public or private, that are serving their profit motive at the expense of their clients. In all, there is governance capacity being created, and it is transparent.

Madagascar is going through no such process. Decentralization has been accompanied by the creation of a National Water and Sanitation Authority but this is a semi-independent body destined to remain highly politicized and relatively toothless. There are some important efforts being made at institutional strengthening. Clarifying the different roles of stakeholders, reorganizing water supply public service, and setting up environmental impact assessments to protect against pollution. However, there is no big picture being drawn. There is no transparency and there is no clear line of oversight associated with municipalities or community organizations. Legislation is few and far between and there is not even a debate about how to establish this effective system of governance.

\subsection{Privatization}

Arguably, the politics of privatization aside, the policy of 
privatization in Israel is well conceptualized. Jerusalem, and municipalities that follow, seem to be going to great lengths to avoid the problems faced in other countries. The (now previous) Chairman of Jerusalem Municipal Water Committee who designed the plan [35] carefully studied England's Ofwat, its mistake of sudden privatization, and associated price increases in 1989. He considered the excessive dividends Ofwat took. He looked at the crisis of privatization in Cochabamba, Bolivia and determined that the problem was not the privatization so much as the increased cost and reduced access to end users. In his view, privatization is blamed for rate increases and decreases in services. In reality the company is doing what the public entity couldn't-removing the price subsidy. He concluded that before privatization the public entity should get the prices right. Then it should ensure the regulatory body is in place to enforce quality and universal delivery laws. Israel's regulatory bodies ensure that excessive dividends are not the reason for water price crises. It took much of a decade for the UK to stabilize its water sector, but it did. Israel has learned from this process. Jerusalem invested $\$ 100$ million in infrastructure to ensure that it is viable. It did this without significant inputs and before privatization. Since end users were paying slightly higher fees to pay for this new infrastructure, the prices will actually fall when privatized as the investors will not be carrying the debt burden. Most end-users will thus support privatization if they notice it at all. Jerusalem is then paying back the remainder of the money borrowed for infrastructure investment with proceeds from the sale.

In contrast, Madagascar's private sector is a virtual free-for-all. There is no viable government oversight. While water is a legally a public good, accessing it is largely an unregulated private activity. Private companies can charge what they like and act as they want. Efforts to sell public municipal water, notably the creation of a public-private partnership or the full sale of the JIRAMA water and electricity utility, interests have been thwarted not by oversight but by the lack of viability. If Cochabamba didn't teach Malagasy municipalities what not to do in looking for a buyer, it certainly taught international water corporations when not to buy. Malagasy municipalities are ill-funded, poorly conceived, and lacking infrastructure. Unlike Jerusalem, it hasn't done the work necessary to make for a viable sale. If it tried it would see significant price increases, a decline in access, and riled end-users. With relatively modest donor assistance investments could be made to make for viable municipal corporations.

In rural areas privatization has most commonly meant water trucks; the prices have been exorbitant and erratic. Based on Israel's example, and what we have learned about the imbalance between delivery type costs, with very limited public investment a private desalination plant could provide water to the region at about onefourth the cost of water from the truck market and onehalf the cost of water provided under subsidy through the AES. This would not help much in resolving water for agricultural purposes, but it would go a long way in providing drinking water. If a lower technology were to be used by a private company to purify river water in the region, this could be provided for less than half the cost of even that.

The current AES process considers only "appropriate" technologies. In so doing it pursues processes that maximize inefficiency while exacerbating environmental degradation. Donors in general, the World Bank in particular, is well placed to guarantee loans that would lead to private investment in infrastructure rather than limited borehole development and gravity wells.

\subsection{Infrastructure Investment}

It may seem an ill-fit to some to compare investment in a wealthy country such as Israel to one of the world's poorest countries. Surely we must consider economies of scale and relative investment quotients. Israel is a developed country and Madagascar is not. This distinction is artificial and obfuscating. The need for regularized water supply and sound water governance is constant across countries. The difference is political, not based on resource capacity, environment needs, or human needs.

If the only viable way to ensure the perpetuation of resource availability into the future is sound management and quality governance then the only way to meet the needs of the present is to assess what those needs are and take the best measures to meet those needs not the best measures to meet those needs within limitations dictated by preconceived notions of what a "developing” country should do. People in Madagascar, in Ambovombe in particular, will continue to suffer from dependence on the World Food Program and other humanitarian organizations. They will continue to suffer from drought, water-borne disease, and malnutrition. They will continue to suffer from imbalanced markets with overpriced resource goods. All until such a time as Madagascar, with external assistance, makes investments in a sustainable resource delivery system. Since people can't be moved to the water, water must be brought to them. That means pipes, that means canals, and that means a viable augmentation in supply.

Israel has made this investment continuously over a fifty-year period. Context is important. It began statesponsored investments in water infrastructure for agricultural, domestic consumption, and industry in 1953 (the worst year on record for Israel's economy). Israel was not a wealthy country then. Its per capita income 
was less than those in Chile, Mauritius, Uruguay, and Venezuela. Yet between independence in 1948 and the creation of the National Water Carrier in 1964 Israel had a chronic current account deficit and regularly increased -not decreased-government expenditures. All infrastructure investments were national and public. It financed it despite a trade deficit that ran between 20 and 35 percent. Gross investment in Israel was very low-the high investment we are used to started only in the early 1970s. It was a low-mid income country-Israel's per capita income in 1964 was about \$US 700 (\$US 4866 in 2010 controlling for inflation). In 1964 Israel had a \$200 million decline in capital flow. During this and other economic crises during the period the international community didn't call on Israel to shrink government investment, it stepped in to ensure it could meet its capital investments. Germany infused the Israeli economy with \$850 million in 1964 (\$5909 million in 2010 dollars) to the benefit of the water infrastructure investment. Israel invested IL 420 million (\$US 140 million in 1964 dollars; \$US 973 in 2010 dollars) worth the National Carrier that year. The concerns of the day were not where the money would come from for the development of infrastructure. They were, as economist NadavHalavi [34] noted shortly thereafter, that "economists in Israel have been inclined to stress the negative implication of the persistent import surplus. The term 'economic dependence' and ideas on how to achieve 'economic independence' are part of almost every discussion of economic policy in Israel”. Even as inflation hit triple digits in the early 1970s investment continued. Today, a functioning system in place, Israel stands to invest four and half billion dollars solely to improve resource governance, not pipes. For this investment, farmers, industrialists, and domestic water users all will have their needs met in one of the world's water poorest countries.

In comparison to these efforts Madagascar's boreholes and gravity pumps appear paltry. The goal may be called "development", but the comparison makes clear that it is a shadow of an effort. It is an admirable effort to reduce short-term human suffering, but nothing more. Madagascar needs principle water infrastructure investment of the sort Israel started in 1953. Development doesn't come at the cost that can be paid by subsistence farmers, gatherers, and herders. The sum total of maximum possible earnings in Ambovombe in a year scarcely breaks US\$2 million. For development to occur capital investment is necessary to compliment the broader vision, improved governance, and new institutions. The international community and, likely, the private sector have a role to play in the infrastructure investment.

\section{Conclusions}

The written record that the single largest challenge in
Madagascar's extreme south is the lack of water resources dates back 350 years. For ninety of the last hundred of those years we have recognized that without water development the betterment of human life is not possible in the region. We have believed that structural investment, not solely community based natural resource management without external organization or investment, is necessary. Based on preliminary evidence, it appears that this view is the one largely held by members of Ambovombe communities. For the people of Ambovombe water is consistently the single largest issue of concern expressed, the lack of modern water infrastructure has been a primary topic for decades [36]. Antandroy have been beyond the pale for education, healthcare, electrification, and road construction. This makes it difficult to separate the issue of water from other development issues. End-users accept that there are costs for water access. However, if water is to be maintained as a human right, disengaging the state process and mandating that full costs be borne by decentralized, water users groups is not a viable process. It is not an acceptable process to water-starved communities. While donor evaluations blame poor governance for project failures a broader view might conclude that there is a disjuncture between community expectations and capacity from new water policy.

Israel's rational confrontation of its water crisis serves as a lesson. As a country it faces even more chronic water shortages than Madagascar. Yet, even while struggling to develop the state has long worked to provide the infrastructure necessary to ensure that water will not be an obstacle to growth. Indeed, in order to struggle to develop the state has long worked to provide the infrastructure necessary to ensure that water will not be an obstacle to growth. As the system began to breakdown, politics in Israel didn't allow for the sort of change necessary. But, today, we see a change. Even as the policy paradigm follows norms of international governance that encourage decentralization and privatization, Israel is doing so with a careful master plan. It has brought all users, across levels, to the table. It has evaluated real needs across sectors. It is taken water governance challenges head on. And, it has started putting in place a system of governance that can oversee lower level management functions in both the public and private sector and ensure that they do not violate the needs of interests, disrupt the resource commons, or create a tragedy.

Madagascar's investment in local water projects to increase the percentage of the population with clean drinking water is admirable. And, seeking alternatives to ineffective state-centric policies is necessary. Yet by presuming that decentralization and open markets can resolve Madagascar's southern water crisis we are assumeing to much. The process has not happened, the institu- 
tions are not in place, and the requisite levels of investment are not forthcoming. Rather than empowering communities as stewards of their own resources, community level management has been undermining effective governance by a receding state, scant economic resources, limited local capacity, and limited local will. Worse, Madagascar's water policies reflect strategies that presume investments need to be made based upon developing economy status (appropriate technologies or what communities can afford), rather than its verifiable resource and human needs. The state of Madagascar lacks the financial capital to make significant capital investments, but even the current expenditure levels could be better used. Donors could contribute more to the amelioration of Madagascar's water sector for the development of Madagascar. But even current funding could be much more creative. Public-private partnerships could focus on supply not just delivery. Modest water infrastructure could be invested in. Subsidies could be placed on water from public utilities, rather than trucks, stretching the investment multi-fold per water unit. Research could focus on conjunctive water use and technological solutions. Environmental research, environmental policy, and tremendously large environmental project could be better integrated with water needs. All water needsagricultural, domestic, and industrial-could be considered together as, ultimately, they are stakeholders seeking the same resource. Presently, the focus is on water poverty alleviation (minimum drinking water thresholds), not development. If Israel had followed the same shortterm, narrow process a century ago, and the international community would have reacted similarly myopic, the desert would not have bloomed and Israel would share an economic strata with Mozambique.

Madagascar's water plan is a giant step forward in meeting basic water needs and alleviating water poverty in the short term. Yet it lacks vision for long-term development. It lacks organization. It lacks management capacity. The days of yore where the state dominates the natural resource policy landscape are thankfully long gone. But, in Madagascar the focus on the community level has provided an opportunity not for cooperation across scales, but for the state to disengage and cut back critical investment and regulatory functions for nascent and fragile community based organizations. As Madagascar, and the international community, turns its back on a long-recognized water scarcity problem, it is perpetuating a cycle of underdevelopment and a future of despair for the Antandroy people.

\section{REFERENCES}

[1] H. Lyautey, "Lettres du Sud de Madagascar: 1900-1902,” Librarie Armand Colin, Paris, 1935.
[2] É. de Flacourt, "Histoire de la Grande Isle Madagascar," INALCO, Karthala, Paris, 1995, p. 1661.

[3] C. Radimilahy and J. A. Rakotoarisoa, "Case Study: Southern Madagascar,” Urban Landscape DynamicsSymposium, Uppsala Universitet, 2003.

[4] J. A. Rakotoarisoa, "Mille ans d'Occupation Humaine dans le Sud-Est de Madagascar: Anosy, Uneile au Milieu des Terre,” Éditions L’Harmattan, Paris, 1998.

[5] K. Wittfogel, "Oriental Despotism: A Comparative Study of Total Power,” Yale University Press, New Haven, 1957.

[6] J. H. Rakotondrainibe, W. H. Randriamanga, M. Rakotomavo and J. Ravelojaona, "Mise à jour de l'etude 20/20 (Document Annexe IV, Secteur Eau et Assainissement)," Republique de Madagascar et Systeme des Nations Unies, Decembre 2001.

[7] I. Droy and J.-L. Dubois, "Gender Inequality in Rural Madagasca R: A Constraint to the Development of Women's Capabilities," Conference Proceedings-Promoting Women's Capabilities: Examining Nussbaum's Capabilities Approach, 9-10 September 2002, Cambridge, 2002.

[8] R. R. Marcus, "Tokana: The Collapse of the Rural Malagasy Community,” African Studies Review, Vol. 51, No. 1, 2008, pp. 85-104.

[9] R. R. Marcus, “Executive Disorder: Madagascar,” Jane’s Intelligence, May 2009.

[10] S. Randrianja, “Madagascar, le Coup d'Etat de 2009,” Karthala, Paris, 2012.

[11] World Bank, "Madagascar Governance and Development Effectiveness Review: A Political Economy Analysis of Governance in Madagascar,” Report No. 54277-MG, Public Sector Reform and Capacity Building Unit, 2010.

[12] E. Ostrom, T. Dietz, N. Dolsak, P. C. Stern, S. Stonich and E. U. Weber, "The Drama of the Commons," National Research Council, Washington DC, 2002.

[13] Economic and Social Research Institute (ESRI), 2012. http://www.arcgis.com

[14] Government of Madagascar, "Enquete Nationale Demographique et Sanitaire 2008-09," Centre National de Recherches sur l'Environnement, 2010.

[15] G. Heurtebize, "Histoire des Afomaraolahy," Centre de Documentation ed de Recherche Surl'Asie du Sud-Est et le Monde Insulindien, Centre National de la Recherche Scientifique, Paris, 1986.

[16] A. Dinar and A. Subramanian, "Water Pricing Experiences: The International Perspective,” World Bank Technical Paper No. 386, 1997.

[17] Direction de L'eau et Assainissement, "Projet Pilote d'Alimentation en Eau Potable et Assainissement en Milieu Rural,” Mission de revue à mi-Parcours, 2002.

[18] Government of Madagascar, "Database of SIGFP/World Bank,” As Calculated by Author.

[19] R. R. Marcus, "Where Community-Based Water Resource Management Has Gone Too Far: Poverty and Disempowerment in Southern Madagascar," Conservation and Development, Vol. 5, No. 2, 2007, pp. 202-231.

[20] B. Minten, R. Razafindralambo, Z. Randriamiarana and B. Larson, "Water Pricing, the New Water Law, and the 
Poor: An Estimation of Demand for Improved Water Services in Madagascar," Cornell Food and Nutrition Policy Program Working Paper No. 129, Cornell University, 2002.

[21] INSTAT (Institut national de la statistique, Madagascar), "Evolution de la Pauvreté à Madagascar: 1993-1999," INSTAT, 2001.

[22] M. W. Rosegrant, X. M. Cai and S. A. Cline, "Global Water Outlook to 2025," International Food and Resource Policy Institute, Washington DC, 2002.

[23] D. Galvan and R. R. Marcus, "Sustainable Development in Sub-Saharan Africa: Resource Management through Institutional Syncretism in Madagascar and Senegal,” In: H. Bressers and W. Rosenbaum, Eds., Achieving Sustainable Development: The Challenge of Governance across Social Scales, Praeger, 2003.

[24] I. Droy, "La Réhabilitation des Petits Périmètres Irrigués à Madagascar: Une Réponse aux Importations de Riz?” Cahiers des Sciences Humaines, Vol. 27, No. 1-2, 1991, pp. 117-127.

[25] R. Bhatia and M. Falkenmark, "Water Resource Policies and the Urban Poor: Innovative Approaches and Policy Imperatives," Water and Sanitation Current, UNDPWorld Bank Water and Sanitation Program, Washington DC, 1993.

[26] State of Israel, “The Water Law of 1959," Ministry of Foreign Affairs, 1998. http://www.israel.org/mfa/go.asp?MFAH0ax30

[27] State of Israel, “The Water Law of 1959,” Ministry of Foreign Affairs: 1.11-1.12, 1959.

[28] H. TokichSharon, "The Evolution of National Wastewater
Management Regimes-The Case of Israel,” Water, Vol. 2, No. 3, 2010, pp. 439-460. doi:10.3390/w2030439

[29] Y. Kislev, "Water Pricing in Israel in Theory and Practice,” Unpublished Paper, Vol. 6, 2010.

[30] R. Laster and D. Livney, "Israel: The Evolution of Water Law and Policy,” In: J. W. Dellapenna and J. Gupta, Eds., The Evolution of Law and Politics in Water, Springer Publishing, New York, 2009. doi:10.1007/978-1-4020-9867-3_8

[31] Israel Water Authority, "Monthly Hydrological Status Report: Surface Water in the Main Drain and Groundwater Levels in the National System,” 2012.

http://www.water.gov.il/Hebrew/ProfessionalInfoAndDat a/Data-Hidrologeime/DocLib2/Hydrological-Report.pdf

[32] N. Becker, D. Lavee and D. Katz, "Desalination and Alternative Water-Shortage Mitigation Options in Israel: A Comparative Cost Analysis,” Journal of Water Resource and Protection, Vol. 2, 2010, pp. 1042-1056. doi:10.4236/jwarp.2010.212124

[33] Y. Kislev, “Urban Water in Israel,” Unpublished Paper, Department of Agricultural Economics and Management, Hebrew University, 2002, Personal Communication.

[34] State of Israel, "Water and Sewage Corporations Law," Knesset, 2001.

[35] Personal Communication, 2005.

[36] M. Bied-Charreton, "Dynamismes Internes et Interventions Externs: Le Parimètrehydroagricole de Behara Dans l'extrème sud de Madagascar," Cahiers ORSTOM, Série Sciences Humaines, Vol. 13, No. 1, 1976, pp. 75-89. 